ARTICLE HISTORY: Received: September 20, 2021 Accepted: November 13, 2021 Published: November 19, 2021

\title{
DEVELOPMENT OF AN EFFECTIVE TECHNOLOGY FOR OBTAINING A FASTENING BASED ON OXIDIZED STARCH AND SYNTHETIC WATER-SOLUBLE POLYMERS
}

\author{
Mardonov Salohiddin Ergashevich \\ PhD Department of Textile technology and design, \\ Bukhara Engineering Technological Institute, Bukhara, Uzbekistan.
}

\begin{abstract}
In the article results of suitable the technology of reception of thickeners for use at stuffing of fabrics on the basis of natural and synthetic polymers received from local source of raw materials are shown. As have shown results of researches, use of polymeric systems on the basis of the oxidised starch as thickener leads to improvement operational and coloristic characteristics of stuffed fabrics.

Key words: textile-auxiliary substances, printing preparations, printing dyes, thickener, compounding, the dye, oxidized starch
\end{abstract}

As you know, an international fair is held annually in our republic. Uzbek cotton, which indicates a large-tonnage production of cotton fibers. For the production of high quality textiles and products from remaining for domestic consumption of cotton fibers are still used imported textile auxiliaries (TWA) and finishing preparations. Topics however, in this aspect, the development of new textile auxiliaries and adhesive - binders for finishing preparations based on local raw materials, as well as application of high-performance technologies is essential in textile industry [1].

Successes in the textile industry, development prospects, role in the national economy and ensuring the quality of life of the population depend on the level of scientific and technological research. The main directions of development of textile industry consists, on the one hand, in the search for new drugs, and on the other hand in search of new efficient technologies for the production high quality and competitive products. Effectiveness in essence is determined by the economy, and its increase ensures a reduction in raw material costs and materials, energy, capital investment and increased productivity [2].

Modern consumer properties of textile materials can be achieved through the development and widespread use of new modern technologies and should be based on effective textile auxiliary substances.

At the domestic textile enterprises of our republic as thickeners When printing cotton fabrics, imported thickening components are mainly used. In this regard, we studied the possibility of replacing them with domestically produced drugs. For this purpose there were

natural and synthetic polymers are used, which are products domestic chemical industry of our republic.

Rheological properties have a great influence on print quality. printing ink and the ability of the thickener to interact with colorants, included in the paint [3]. For high quality patterned colors on fabrics of any class of dyes are applied to printing inks the following requirements:

1.Good consistency with sufficient color retention and thereby to ensure sufficient clarity of the pattern and the absence of leakage when printing on fabric;

2. Evenly and completely transferring to the fabric during the printing process;

3.The printing ink should wet the print roller engraving well and stay in it;

4.Good to penetrate the sieve of the template (when printing with mesh templates) and do not clog it when typing;

5.The loose part of the ink should be well washed off the fabric. when flushing;

6.Have good storage stability and high storage stability different operating modes of printing machines.

Based on the data obtained, we have developed the composition of the thickening used for stuffing cotton fabrics based on oxidized rice starch (table 1) [4]. 
Table 1.

Thickener Formulation for Different Dye Classes

\begin{tabular}{|c|c|c|c|c|}
\hline \multirow{2}{*}{$\begin{array}{l}\text { Composition of the } \\
\text { thickener }\end{array}$} & \multicolumn{2}{|c|}{ for active dyes } & \multicolumn{2}{|c|}{ for azo dyes } \\
\hline & tradition & the proposed & tradition & the proposed \\
\hline Sodium alginate & 25 & - & - & - \\
\hline Oxidized starch $(\mathrm{OK})$ & - & 60 & - & 50 \\
\hline GIPAN & - & 0.8 & - & 1.2 \\
\hline Uniflock & - & 1.0 & - & 1.0 \\
\hline Pologen & - & - & 50 & - \\
\hline Sodium hydroxide & - & - & 10 & - \\
\hline Glycerol & - & - & 30 & - \\
\hline Magnesium sulfate & - & - & 30 & - \\
\hline $\begin{array}{l}\text { Thickening starch - } \\
\text { tragant }\end{array}$ & - & - & 90 & - \\
\hline Bicarbonate of soda & 10 & - & - & - \\
\hline Sodium acetate & - & - & 10 & - \\
\hline Chloramine & - & - & 0.72 & \\
\hline Urea & 100 & 100 & 100 & 100 \\
\hline Ludigol & 10 & 10 & 10 & 10 \\
\hline Water & & Up to 1000 & & \\
\hline
\end{tabular}

To begin with, several ink recipes were tried. During preliminary experiments, it was taken into account that all components are well combined together. The main difference between printing ink and dye solution is the presence of a thickener in it, which forms a specific internal structure. The given composition, which is a structured aqueous solution natural and synthetic hydrophilic polymers, meets the same requirements [5].

As can be seen from the data in Table 1, with the introduction of synthetic polymers a reduction in the consumption of food starch obtained from secondary products when processing rice. The use of polymer systems based on OK in as a thickener leads to improved performance and color characteristics of printed fabrics.

Based on the results of preliminary studies of the intensity of the colors, character of shade, resistance to soap and sweat, wet and dry rubbing were chosen various formulations of printing inks. More efficient in terms of color the indicator turned out to be the composition of the printing ink with a thickening polymer system, which contains $\mathrm{g} / \mathrm{kg}$ : oxidized starch (OK) - 60.0, GIPAN-0.8, unifloc-1.0. It has been found that sodium metasilicate thickener does not impair coloristic properties of the printed drawings. Coloristic characteristics are presented in table 2.

Table 2.

Color characteristics of printed fabrics

\begin{tabular}{|c|c|c|c|c|c|}
\hline $\begin{array}{c}\text { Components included in } \\
\text { thickener composition }\end{array}$ & $\begin{array}{c}\text { Color } \\
\text { tone, } \lambda \\
\text { house, } \mathrm{nm}\end{array}$ & $\begin{array}{c}\text { Brightness of color, } \\
\text { cd } / \mathrm{m}^{2}\end{array}$ & Purity of color, $\mathrm{p}$ & Color intensity, K / S & $\begin{array}{c}\text { Uneven } \\
\text { that color } \\
\text { ki, compare max }\end{array}$ \\
\hline Oxidized starch $(\mathrm{OK})$ & $\mathbf{4 7 7}$ & $\mathbf{3 6 6 9}$ & $\mathbf{0 . 5 3}$ & $\mathbf{9 . 7}$ & $\mathbf{0 . 4 2}$ \\
\hline OK - GIPAN & $\mathbf{4 8 0}$ & $\mathbf{3 5 3 8}$ & $\mathbf{0 . 4 7}$ & $\mathbf{1 . 4 1}$ & $\mathbf{0 . 2 6}$ \\
\hline OK - uniflock & $\mathbf{4 7 8}$ & $\mathbf{3 8 9 2}$ & $\mathbf{0 . 5 1}$ & $\mathbf{1 3 . 1}$ & $\mathbf{0 . 1 7}$ \\
\hline OK-GIPAN-uniflock & $\mathbf{4 8 1}$ & $\mathbf{4 5 4 3}$ & $\mathbf{0 . 6 5}$ & $\mathbf{1 5 . 5}$ & $\mathbf{0 . 1 5}$ \\
\hline
\end{tabular}

Studies have shown that the correct thickener and other components of the polymer system give the printing ink sufficient viscosity, brightness and color strength, plasticity, and other properties [6].

From the data obtained, it can be seen that the color tone of the printed fabrics for all compositions does not differ significantly, while the color intensity is the highest for the OK, GIPAN and uniflock compositions. It is known that when printing fabrics, the process of heat setting is a mandatory procedure. Usually heat setting is carried out at sufficiently high temperatures of the order of $130-150{ }^{\circ} \mathrm{C}$ and is aimed at determining and intensify the chemical processes taking place in the printed layer with the formation of chemical crosslinks [7].

We have studied the effect of temperature and duration of curing for the durability of coloring (azo dyes) to physical and chemical influences. Samples fabrics printed according to the composition: OK, GIPAN and uniflock were 
heat-set at temperatures $120,130,140,150$ and $160{ }^{\circ} \mathrm{C}$. The samples obtained were tested to physical and chemical influences. The results are shown in Table 3.

The data obtained show that with an increase in the fixation temperature the color strength increases. Already at $120^{\circ} \mathrm{C}$ satisfactory results in washing, dry and wet friction and perspiration. Usually heat-set carried out at a temperature of $140-150{ }^{\circ} \mathrm{C}$ for 3-5 minutes. Anchoring polymer system, in particular $\mathrm{OK}$ and other ingredients of the printing ink occurs due to the formation of a mesh structure of the printed composition on cotton fiber.

Table 3.

Influence of heat setting conditions for printed fabrics on their performance

\begin{tabular}{|c|c|c|c|c|c|c|c|c|c|}
\hline \multirow{3}{*}{$\begin{array}{c}\text { Температура } \\
\text { фиксации, } \\
{ }^{\circ} \mathrm{C}\end{array}$} & \multirow{3}{*}{$\begin{array}{c}\text { Время термо } \\
\text { фиксации, } \\
\text { мин. }\end{array}$} & \multicolumn{8}{|c|}{ Прочность окраски, баллы } \\
\hline & & \multicolumn{2}{|c|}{$\begin{array}{c}\text { к сухому } \\
\text { трению }\end{array}$} & \multicolumn{2}{|c|}{$\begin{array}{c}\text { к мокрому } \\
\text { трению }\end{array}$} & \multicolumn{2}{|c|}{ к стирке } & \multicolumn{2}{|c|}{ к поту } \\
\hline & & $\begin{array}{l}\text { Базо } \\
\text { вый }\end{array}$ & $\begin{array}{c}\text { пред } \\
\text { ложен }\end{array}$ & $\begin{array}{l}\text { Базо } \\
\text { вый }\end{array}$ & $\begin{array}{c}\text { пред } \\
\text { ложен }\end{array}$ & $\begin{array}{l}\text { Базо } \\
\text { вый }\end{array}$ & $\begin{array}{c}\text { пред } \\
\text { ложен }\end{array}$ & $\begin{array}{l}\text { Базо } \\
\text { вый }\end{array}$ & $\begin{array}{c}\text { пред } \\
\text { ложен }\end{array}$ \\
\hline \multirow{2}{*}{120} & 3 & $5 / 3$ & $5 / 3$ & $5 / 3$ & $5 / 3$ & $5 / 3$ & $5 / 4$ & $5 / 4$ & $5 / 4$ \\
\hline & 5 & $5 / 4$ & $5 / 4$ & $5 / 3$ & $5 / 4$ & $5 / 4$ & $5 / 5$ & $5 / 3$ & $5 / 4$ \\
\hline \multirow{2}{*}{130} & 3 & $5 / 3$ & $5 / 3$ & $5 / 3$ & $5 / 4$ & $5 / 3$ & $5 / 4$ & $5 / 4$ & $5 / 4$ \\
\hline & 5 & $5 / 4$ & $5 / 3$ & $5 / 4$ & $5 / 4$ & $5 / 4$ & $5 / 4$ & $5 / 4$ & $5 / 4$ \\
\hline 140 & 3 & $5 / 4$ & $5 / 4$ & $5 / 3$ & $5 / 3$ & $5 / 4$ & $5 / 4$ & $5 / 5$ & $5 / 4$ \\
\hline 150 & 3 & $5 / 5$ & $5 / 4$ & $5 / 4$ & $5 / 4$ & $5 / 4$ & $5 / 5$ & $5 / 3$ & $5 / 4$ \\
\hline 160 & 1 & $5 / 5$ & $5 / 3$ & $5 / 4$ & $5 / 4$ & $5 / 4$ & $5 / 5$ & $5 / 4$ & $5 / 5$ \\
\hline
\end{tabular}

In connection with the above, we have developed a composition and technology for obtaining new thickeners used for printing cotton fabrics. On on the basis of research carried out in laboratory conditions and production tests developed a technology for obtaining a thickener based on water-soluble polymers. The technology of obtaining thickeners for printing inks on based on oxidized starch and water-soluble polyacrylates consists of next [8].

Cold water $2 / 3$ of the volume is poured into a clean washed reactor 1 and loaded a certain amount of oxidized starch with continuous stirring in within 10 minutes. After that, the estimated amount of GIPAN and uniflok is entered, water is added to the volume of the reactor, i.e. up to 1000 liters. Then dry steam is supplied and bring the boiling point to $800 \mathrm{C}$ and cook for 50-60 minutes polymer mixture until a homogeneous mass is obtained [9].

The resulting homogeneous mass of thickener is pumped into container $2(501)$ and cools down to a temperature of 30-400C. After settling through a measuring tank the appropriate amount of thickener is supplied to obtain the printing ink. On at this stage, the calculated amount of the following components is introduced into the container 3 (1000 l) to obtain the printing ink: urea and ludigol. And then it is introduced and the estimated amount of dye[10,11].

Taking into account the data presented in tables $1-3$ and the fact that rice starch is obtained from by-products, rice processing, and GIPAN and unifloc, produced on an industrial scale, economic the feasibility and use of them becomes apparent.

\section{References}

1. Praise A., Anger V., Praise K . Textile auxiliary substances. // Per. with him. ed. G.E. Krichevsky. -M.: Legprombytizdat, 1991. p.423.

2. Krichevsky G.E. Main trends in the development of chemical finishing technology textile materials. Revolution or evolution. // Text. chemistry. 1997 Specialist issue number 1 (10). pp.14-34.

3. Moryganov A.P., Zakharov A.G., Zhivetin V.V. Materials for chemical and textile production // Ros. chem. f. (J. Russian chemical society named after DI. Mendeleev), 2002, vol. XLVI, No. 1. pp. 58-66.

4. Mardonov S.E., Sharipov M.S. Structural and mechanical properties of new sizing compositions based on natural and synthetic water-soluble polymers // "Development of Science and Technology" Scientific and technical journal №3 / 2018, pp. 77-81.

5. Development of an effective technology for producing a thickener based on oxidized starch and synthetic water-soluble polymers // Sharipov M.S., Mardonov S.E., Ravshanov K.A. "Development of science and technology" Scientific and technical journal №3 / 2018, pp.82-86.

6. Abrorov A, Kuvoncheva M, Rajabov O, Mukhammadov M and Jumaev S 2020 Method of thermal treatment of saw disk teeth of fiber-processing machines by laser quenching. IOP Conference Series: Materials Science and Engineering 862032034.

7. Sharipov M.S. Assessment of the conditional indicator of the structure is traditionally used and developed polymer-composite thickeners // Abstracts of the XX All-Russian Conference of Young Scientists-Chemists. Nizhny Novgorod, 2017 .p.553.

8. 7.S. Mardonov., S. Khamraeva., K. Muminov., Kh. Rakhimov., E.Kuldoshev// Analysis of Quality Indicators 
of Sizing Warp Threads International Journal of Advanced Science and Technology Vol. 29, No.4, (2020), pp. 4957 4968.

9. Mardonov S.E. "The use of local preparations for sizing yarn" International Journal of Advanced Research in Science, Engineering and Technology, Volume 6, Issue 12, December 2019. pp. 12281-12287

10. S.E. Mardonov., R.Kh. Nurboev., F.F. Kazakov., M.C.Khidoyatova// Development of a new composition for sizing the warp thread. International Journal of Advanced Research in Science, Engineering and Technology Vol. 7, Issue 6 , June 2020. pp. 14044- 14048

11. S.E. Mardonov., N. Yusupova // Movement Of The Flexible Thread System In The Viscous Fluid Stream. Journal of Multidisciplinary Engineering Science and Technology (JMEST) ISSN:2458-9403 Vol. 4 Issue 3, March 2017. pp. 6956-6958. 